Research Paper

\title{
17beta-estradiol Attenuates TNF- $\alpha$-Induced Premature Senescence of Nucleus Pulposus Cells through Regulating the ROS/NF-KB Pathway
}

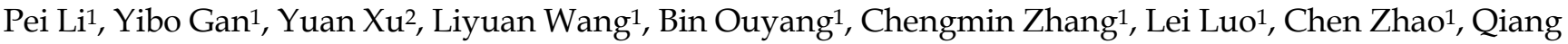 \\ Zhou $^{1 凶}$ \\ 1. Department of Orthopedic Surgery, Southwest Hospital, Third Military Medical University, Chongqing, 400038, China. \\ 2. Department of Orthopedic Surgery, Xinqiao Hospital, Third Military Medical University, Chongqing, 400037, China. \\ $\triangle$ Corresponding author: Tel: + 86-023-68765283. Fax: + 86-023-65340297. E-mail: zq_tlh@163.com. \\ (c) Ivyspring International Publisher. This is an open access article distributed under the terms of the Creative Commons Attribution (CC BY-NC) license \\ (https://creativecommons.org/licenses/by-nc/4.0/). See http://ivyspring.com/terms for full terms and conditions.
}

Received: 2016.07.07; Accepted: 2016.10.19; Published: 2017.01.15

\begin{abstract}
Background: Accelerated cellular senescence within the nucleus pulposus (NP) region is a common feature of disc degeneration. Our previous work indicated that TNF- $\alpha$ promoted NP cell senescence. Although the intervertebral disc has been reported to be an estrogen-sensitive tissue, it is unclear whether estrogen can inhibit premature senescence of NP cells.

Objective: To investigate whether 17 beta-estradiol $\left(E_{2}\right)$ can attenuate TNF- $\alpha$-induced premature senescence of NP cells and the potential mechanism behind this regulatory process.

Methods: Isolated NP cells and intact intervertebral discs from healthy rats were cultured with or without TNF- $\alpha, E_{2}$ or their combination. The pan estrogen receptor (ER) antagonist ICl 182780 was used to investigate the role of ER. Direct and indirect indicators including cell proliferation, SA- $\beta$-Gal activity, telomerase activity, cell cycle, and the expression of matrix macromolecules (aggrecan and collagen II) and senescence markers (p16 and p53) were used to evaluate the premature senescence of NP cells. Additionally, intracellular reactive oxygen species (ROS) and NF-KB/p65 activity were also detected in the NP cell cultures.

Results: In the NP cell cultures, $E_{2}$ significantly increased cell proliferation potency, telomerase activity and the expression of matrix macromolecules but attenuated SA- $\beta-G a l$ activity, senescence marker (p53 and p16) expression and Gl cycle arrest in TNF- $\alpha$-treated NP cells. Furthermore, $E_{2}$ inhibited ROS generation and phospho-NF-KB/p65 expression in the TNF-a-treated NP cells. However, the ER antagonist ICI 182780 abolished the effects of $E_{2}$ on TNF- $\alpha$-treated NP cells. In the disc organ cultures, $E_{2}$ also significantly increased matrix synthesis, whereas it decreased senescence marker ( $\mathrm{p} 53$ and $\mathrm{p} 16$ ) expression, which could be abolished by the ER antagonist ICl 182780.

Conclusion: The interaction between $E_{2}$ and ER can attenuate TNF- $\alpha$-induced premature senescence of rat NP cells through interfering with the ROS/NF-KB pathway.
\end{abstract}

Key words: intervertebral disc degeneration, nucleus pulposus, cell senescence, estrogen, TNF- $\mathrm{a}$.

\section{Introduction}

Intervertebral disc degeneration (IDD) is a potential contributor to low back pain (LBP). Epidemiology data demonstrate that approximately $80 \%$ of adults suffer LBP during their lifetime [1]. Due to the underappreciated pathogenesis and unsatisfactory therapeutic results [2, 3], disc degeneration has become a research focus worldwide.

Disc degeneration is regarded as a natural process of disc aging [4, 5]. Additionally, accelerated aging of nucleus pulposus (NP) cells is one of the 
major cellular processes associated with disc degeneration [6, 7]. Previous studies have demonstrated that senescent disc cells increased with advancing disc degeneration and accumulated in herniated discs [8-10]. In addition to cellular senescence, the inflammation process is another pathological phenomenon that becomes aggravated with advancing disc degeneration [11-17]. As a typical inflammatory cytokine, TNF- $\alpha$ can increase the generation of reactive oxygen species (ROS), which interacts with several signaling molecules along cell apoptosis and cell proliferation pathways, such as the common nuclear factor-kB (NF-kB) pathway [14, 18]. In the previous study, we found that the inflammation cytokine TNF- $\alpha$ can significantly promote premature senescence of NP cells. Similarly, premature senescence of other cell types is also related with increased inflammatory cytokines [19, 20]. Based on these facts, we deduced that the inhibition of inflammatory cytokine-induced senescence of NP cells may be a possible strategy for the prevention and treatment of disc degeneration.

Recent evidence has indicated that sex hormones can influence the severity of disc degeneration [21]. A previous study demonstrated that female discs appear to degenerate at a notably faster rate than male discs between the age of 50 and 60 years [22]. Moreover, estrogen supplementation tends to increase disc height in post-menopausal women [23], whereas female rats easily developed disc degeneration after undergoing ovariectomy [24]. Additionally, 17beta-estradiol $\left(\mathrm{E}_{2}\right)$ is able to inhibit apoptosis of disc cells and promote the proliferation of disc cells [25-29]. Taken together, these studies confirm that intervertebral discs are estrogen sensitive tissues and indicate that estrogen may play a protective role against disc degeneration.

It is currently unknown that whether estrogen can inhibit premature senescence of NP cells. Because we found that the inflammatory cytokine TNF-a can promote premature senescence of NP cells in our preliminary work, the present study primarily sought to investigate whether $\mathrm{E}_{2}$ can attenuate TNF-a-induced senescence of NP cells in disc NP cell cultures and intact disc organ cultures. The estrogen receptor (ER) antagonist ICI 182780 was used to investigate the role of ER in this regulatory process. NP cell senescence was analyzed through various direct or indirect parameters, including cell proliferation, telomerase activity, cell cycle, SA- $\beta-$ Gal activity, expression of matrix macromolecules (aggrecan and collagen II) and senescence markers (p16 and p53). The intracellular ROS and the activity of the NF-kB pathway were analyzed to investigate the possible mechanism underlying the protective role of $\mathrm{E}_{2}$ against TNF- $\mathrm{a}$-induced NP cell senescence.

\section{Materials and Methods}

\section{Part 1: NP cell culture study}

Isolation and culture of NP cell

Twenty-five Sprague-Dawley rats (male, $250 \mathrm{~g}$ and 6-8 weeks old) were used according to the role of the Ethics Committee at Southwest Hospital affiliated to the Third Military Medical University [SYXK (YU) 2012-0012]. Female rats were not chosen to avoid interference of the menses cycle. Briefly, the lumbar discs (L1-L5) were removed under sterile conditions after the rats were sacrificed with excess carbon dioxide inhalation. Thereafter, the innermost NP tissue was harvested under a dissecting microscope. After sequential enzymatic digestion with $0.25 \%$ trypsin for $5-10$ minutes and $0.25 \%$ type I collagenase (Sigma) for 20-25 minutes, the NP cell pellets were collected and re-suspended in monolayer culture with DMEM/F12 medium (Hyclone) containing 10\% (v/v) fetal bovine serum (FBS, Gibco) and $1 \%$ (v/v) penicillin-streptomycin (Gibco) under standard conditions $\left(37^{\circ} \mathrm{C}, 21 \% \mathrm{O}_{2}\right.$ and $\left.5 \% \mathrm{CO}_{2}\right)$. The culture medium was changed every 3 days, and the NP cells were subcultured at a ratio of 1:3 after reaching $80 \%$ confluence. Because in vitro subcultivation can lead to senescence of NP cells [30], the passage 2 (P2) NP cells were used in this study.

\section{Grouping}

TNF- $\alpha$ is a typical inflammatory cytokine within degenerated discs $[31,32]$ and TNF- $\mathrm{a}(10 \mathrm{ng} / \mathrm{mL})$ can induce the premature senescence of NP cells according to our preliminary work. Therefore, TNF-a was added to the culture medium to induce premature senescence of NP cell in this study. To investigate whether estrogen can inhibit TNF-a-induced NP cell senescence and to elucidate the role of ER, the following groups were designed in this study. Group 1 was treated with PBS as a control. Group 2 was treated with $10 \mathrm{ng} / \mathrm{mL}$ TNF-a. Group 3 was treated with $10 \mathrm{ng} / \mathrm{mL}$ TNF- $\alpha$ and $10^{-7} \mathrm{M} \mathrm{E}_{2}$. Group 4 was treated with $10 \mathrm{ng} / \mathrm{mL}$ TNF-a, $10^{-7} \mathrm{M} \mathrm{E}_{2}$ and $10 \mu \mathrm{M}$ ICI 182780. Concentrations of $\mathrm{E}_{2}$ and ICI 182780 were selected according to previous studies $[28,33]$. Because menopause plays an important role in promoting disc degeneration, we also selected an $\mathrm{E}_{2}$ concentration of 10-7 $\mathrm{M}$ because it represents estrogen serum levels in premenopausal women [34].

\section{CCK-8 assay}

NP cells were seeded in 48 -well plates $\left(4 \times 10^{3}\right.$ cells/well) and incubated with different test compounds for 24 and 48 hours, respectively. Then, 
after NP cells were incubated with fresh medium containing CCK-8 working solution (Beyotime, China) for 2 hours, the absorbance at $450 \mathrm{~nm}$ wavelength was measured to indicate cell proliferation potency using an automatic microplate reader (Thermo).

\section{SA- $\beta$-Gal activity}

NP cells were seeded in 6-well plates and incubated with different test compounds for 24 hours. Then, SA- $\beta-$ Gal staining was performed using a Senescence $\beta$-Galactosidase Staining Kit (Beyotime, China) and the SA- $\beta$-Gal staining-positive NP cells were observed under a light microscope (Olympus BX51). SA- $\beta$-Gal activity was expressed as the percentage of SA- $\beta$-Gal positive NP cells.

\section{Telomerase activity measurement}

$\mathrm{NP}$ cells were seeded in petri dishes $(10-\mathrm{cm}$ diameter $1.0 \times 10^{4}$ cells per dish) and incubated with different test compounds for 24 hours. After NP cell pellets were lysed and centrifuged to collect the supernatant, telomerase activity (IU/L) was measured using a telomerase (TE) ELISA kit (Mlbio, China) according to the manufacturer's instructions.

\section{Cell cycle analysis}

NP cells were seeded in petri dishes $(10-\mathrm{cm}$ diameter, $3 \times 10^{4}$ cells per dish) and grown to $70-80 \%$ confluence. After serum-starvation for 4 hours, NP cells were incubated with different test compounds for 24 hours. Thereafter, the NP cells were digested with trypsin $(0.25 \%$ without EDTA, Gibco) and centrifuged to collect the cell pellets. After fixation with $75 \%$ ethanol and staining with propidium iodide dye (50 ug/ml, Beyotime, China) for 30 minutes, NP cells were subjected to flow cytometry analysis. The cell cycle of each group was analyzed using multicycle software (Japan PHENIX Company).

\section{Intracellular ROS measurement}

The intracellular ROS content of the NP cells was measured using a reactive oxygen species assay kit (Nanjing Jiancheng Bioengineering Institute, China) according to the manufacturer's instructions. Briefly, after incubation with different test compounds, NP cells were incubated with DCFH-DA $(10 \mu \mathrm{M})$ for 40 minutes. Then, the NP cells were harvested by digestion with $0.25 \%$ trypsin and $10^{5}$ cells in each group were used to measure the intracellular ROS expressed as fluorescence intensity at an excitation/emission wavelength of 490/585 nm.

\section{Real-time PCR analysis}

The gene expression of senescence markers (p16 and p53) and extracellular matrix (aggrecan and collagen II) was analyzed by real-time PCR. Briefly, after NP cells were incubated with different test compounds for 24 hours, $1 \mu \mathrm{g}$ RNA extracted using Tripure Isolation Reagent (Roche) was synthesized into cDNA using a First Strand cDNA Synthesis Kit (Roche). Then, a reaction system containing cDNA, SYBR Green Mix (TOYOBO) and primers (Table 1) was subjected to real-time PCR machine (CFX96 Real-Time System, Bio-Rad). $\beta$-actin was used as an internal reference, and the relative gene expression was expressed as $2^{-\Delta \Delta \mathrm{Ct}}$.

\section{Immunocytochemistry staining}

Expression of matrix macromolecules (aggrecan and collagen II) and ERs (ERa and ER $\beta$ ) was analyzed by immunocytochemistry. Briefly, NP cells were first fixed with $4 \%$ paraformaldehyde and blocked with $5 \%$ bovine serum albumin. After incubation with primary antibodies (ERa: Proteintech, 21244-1-AP, diluted 1:100; ER $\beta$ : Abcam, ab3576, diluted 1:200; aggrecan: Novus, NB120-11570, diluted 1:200; collagen II: Abcam, ab34712, diluted $1: 200$ ) at $4^{\circ} \mathrm{C}$ overnight and incubation with the corresponding secondary antibodies conjugated with HRP (ZSGB-BIO, China, diluted 1:200) at $37^{\circ} \mathrm{C}$ for 2 hours, color development was achieved using diaminobenzidine (DAB). Finally, the NP cells were observed under a light microscopy (Olympus BX51, Japan) and immunostaining intensity was analyzed using Image-Pro Plus software (Version 5.1, Media Cybernetics, Inc.).

\section{Western blotting analysis}

The protein expression of senescence markers (p16 and p53), matrix molecules (aggrecan and collagen II), NF-kB p65, phospho-NF-kB p65 and ERs (ERa and ER $\beta$ ) was analyzed by Western blotting assay. Briefly, NP cells were incubated with different

Table 1. Primers of target genes.

\begin{tabular}{llll}
\hline Gene & Accession number & Forward $\left(5^{\prime}-3^{\prime}\right)$ & Reverse $\left(5^{\prime}-3^{\prime}\right)$ \\
\hline$\beta$-actin & NM_031144.3 & CCGCGAGTACAACCTTCTTG & TGACCCATACCCACCATCAC \\
Aggrecan & XM_002723376.1 & ATGGCATTGAGGACAGCGAA & GCTCGGTCAAAGTCCAGTGT \\
Collagen II & NM_012929.1 & GCCAGGATGCCCGAAAATTAG & CCAGCCTTCTCGTCAAATCCT \\
P53 & XM_008767773.1 & CCTTAAGATCCGTGGGCGT & GCTAGCAGTTTGGGCTTTCC \\
P16 & NM_031550.1 & TACCCCGATACAGGTGATGA & TACCGCAAATACCGCACGA \\
\hline
\end{tabular}


test compounds for 24 hours, and the total protein was extracted using RIPA solution (Beyotime, China). Then, the protein samples were subjected to SDS-PAGE system and transferred to PVDF membranes. After incubation with primary antibodies (NF-kB p65: Beyotime, AV365; phosphor-NF-kB p65: Beyotime, AV371; p16: Novus, NBP2-37740; p53: Proteintech, 10442-1-AP; $\beta$-actin, Proteintech, 60008-1-Ig. All diluted at a ratio of $1: 1000)$ at $4^{\circ} \mathrm{C}$ overnight and incubation with the corresponding secondary antibodies (ZSGB-BIO, China, diluted $1: 2000)$ at $37^{\circ} \mathrm{C}$ for 2 hours, protein bands were visualized using a SuperSignal West Pico Trial Kit (Thermo). Finally, protein expression normalized to $\beta$-actin was analyzed using Image $\mathrm{J}$ software (National Institutes of Health, USA).

\section{Part 2: Intact disc organ culture study}

\section{Disc harvest and organ culture}

Twelve Sprague Dawley rats (male, $350 \mathrm{~g}$ and 12 weeks old) were used in this experiment. According to previous methods, lumbar discs ( $\mathrm{N}=4$ /animal, L1-L5) were separated under sterile conditions. Then, as much vertebral bone as possible was removed under a dissecting microscope. After being washed with phosphate buffer solution, the discs were placed in 6-well plates and maintained for 10 days in DMEM/F12 (Hyclone) supplemented with 10\% fetal bovine serum (FBS, Gibco) and $1 \%$ penicillin/streptomycin (Hyclone) under standard conditions $\left(37^{\circ} \mathrm{C}, 21 \% \mathrm{O}_{2}\right.$ and $\left.5 \% \mathrm{CO}_{2}\right)$. In general, four groups in this experiment were designed as follows: Group 1 was treated with PBS as a control. Group 2 was treated with $200 \mathrm{ng} / \mathrm{mL}$ TNF-a. Group 3 was treated with $200 \mathrm{ng} / \mathrm{mL}$ TNF- $\alpha$ and $10^{-7} \mathrm{M} \mathrm{E}_{2}$. Group 4 was treated with $200 \mathrm{ng} / \mathrm{mL}$ TNF-a, $10^{-7} \mu \mathrm{M}$ $\mathrm{E}_{2}$ and $10 \mu \mathrm{M}$ ICI 182780. All test compounds were added along with the culture medium for 10 days. Because the substance diffusion distance into the central NP region is relatively large for organ-cultured intact disc, a higher TNF-a concentration $(200 \mathrm{ng} / \mathrm{mL})$ than that used in the cell culture was chosen for the organ-cultured rat discs according to a previous study [35]. In light of the difference between different disc levels, discs from the same levels were used for the same assays in this study. For example, the same 3 discs (L1/2 or L2/3) from different animals were used for the western blotting analysis.

\section{Real-time PCR and western blotting assay}

After 10 days, the inner most NP tissue was removed under a dissecting microscope. Then, real-time PCR and western blotting assays were performed as described above to analyze the gene expression and protein expression of matrix macromolecules (aggrecan, Santa Cruz, sc-16492, diluted 1:500; collagen II, Abcam, ab34712, diluted 1:1000) and senescent markers (p16 and p53), respectively.

\section{Biochemical content measurement}

After the inner most NP tissue was removed at day 10, the wet weights of the NP tissue used for glycosaminoglycan (GAG) content and hydroxyproline (HYP) content quantification were immediately measured using a precision electronic autobalance. Thereafter, the NP tissue used for GAG content measurement was digested with papain solution for $12-15$ hours at $60^{\circ} \mathrm{C}$. Then, GAG content normalized to the tissue wet weight was analyzed using a dimethylmethylene blue (DMMB) assay [36] in which shark cartilage chondroitin sulfate was used as a standard. HYP content as a measure of collagen content was determined using a HYP quantification kit (NanJing JianCheng, China).

\section{Immunohistochemistry assay}

After incubation with different test compounds, the discs were sequentially fixed with $4 \%$ paraformaldehyde for 24 hours, decalcified with $10 \%$ ethylenediaminetetraacetic acid (EDTA) for 10 days, embedded in paraffin and sectioned. Thereafter, the prepared 5- $\mu \mathrm{m}$-thick cross-sections were used for immunostaining of aggrecan and collagen II as described above.

\section{Statistics}

Significant difference was analyzed using SPSS 13.0 software. All quantitative data were expressed as the mean $\pm S D$ of three independent experiments in this study. When the homogeneity test for variance was completed, comparisons among multiple groups were performed using one-way analysis of variance (ANOVA) followed by LSD post hoc test. A significant difference was indicated for a p-value $<0.05$.

\section{Results}

\section{Part 1: Results of the NP cell culture study}

Identification of ERs (ER $\alpha$ and $E R \beta)$ expression in NP cells

Because the role of the interaction between E2 and ER was investigated in this study, we first analyzed whether ERs (ERa and ER $\beta$ ) are expressed in NP cells. In line with previous studies $[25,28]$, the immunocytochemistry assay indicated cytoplasmic localization of ERa and ER $\beta$ in the NP cells. However, no significant difference in ERa expression or ER $\beta$ 
expression was found among these four groups in the western blotting assay, indicating that $\mathrm{E}_{2}$, TNF- $\mathrm{a}$ and antagonist ICI 182780 do not affect ER expression of NP cells in this study.

\section{$E_{2}$ significantly promoted proliferation of TNF-a-treated NP cells}

Senescent cells often have limited cell proliferation potency. NP cell proliferation in each group was analyzed via CCK-8 assays. As shown in Figure 2, the proliferation potency of TNF-a-treated NP cells was significantly decreased compared to the control group. However, $\mathrm{E}_{2}$ increased the proliferation potency of TNF-a-treated NP cells. When the ER function was inhibited by the antagonist ICI 182780, the effects of $E_{2}$ on the proliferation potency of TNF-a-treated NP cells were significantly prohibited.
These results suggesting that $\mathrm{E}_{2}$ could attenuate the inhibitory effects of TNF-a on NP cell proliferation through ER function.

\section{$E_{2}$ reduced SA- $\beta-G$ al activity of TNF- $\alpha$-treated NP cells}

SA- $\beta$-galactosidase staining is a useful assay for identifying senescent cells. Compared to the control group, TNF-a significantly increased the number of SA- $\beta$-Gal positive-stained NP cells, whereas $E_{2}$ markedly abolished the effects of TNF- $\alpha$ on SA- $\beta-$ Gal activity of the NP cells (Figure 3 ). The addition of ICI 182780 into the culture medium significantly increased the SA- $\beta$-Gal activity in $\mathrm{E}_{2}$-treated NP cells. Taken together, these findings indicate that ER was involved in the effects of $E_{2}$ on the SA- $\beta$-Gal activity of TNF-a-treated NP cells.
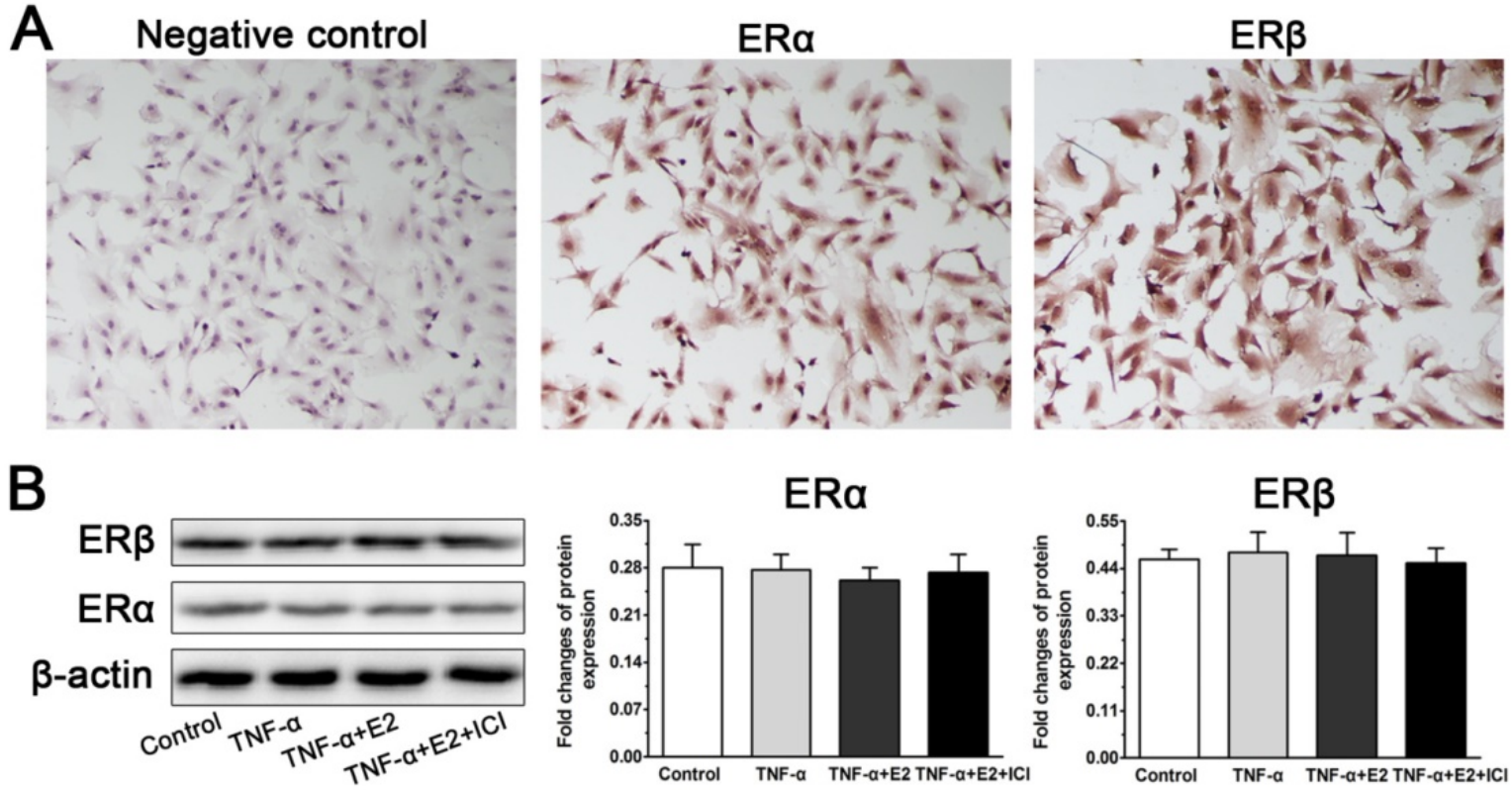

Figure 1. Identification of estrogen receptor (ER) expression in rat nucleus pulposus (NP) cells. A: The immunocytochemistry assay indicated cytoplasmic localization of ERa and $E R \beta$ in the NP cells. B: No significant differences in ERa expression or ER $\beta$ expression were found among these designed groups in the western blotting assay. Data are expressed as the mean $\pm \operatorname{SD}(n=3)$.

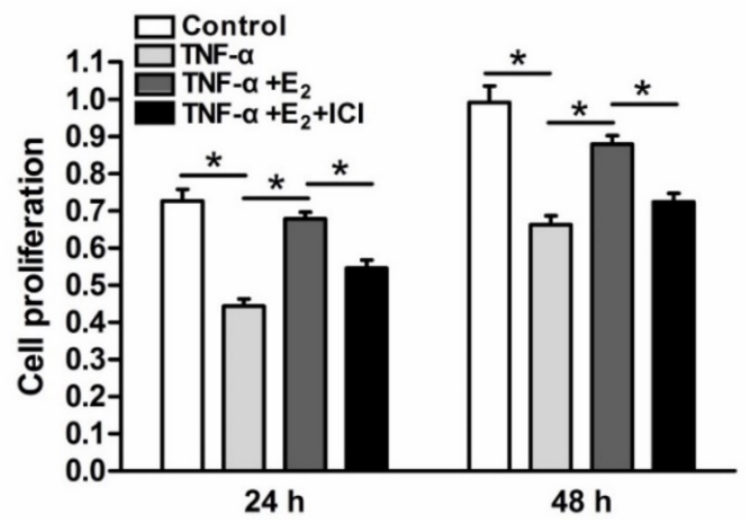

Figure 2. 17beta-estradiol $\left(E_{2}\right)$ significantly promoted the proliferation of TNF- $\alpha$-treated nucleus pulposus (NP) cells. NP cells were incubated with different test compounds for 24 hours and 48 hours. Data are expressed as the mean $\pm S D(n=3)$. *: significant difference between two groups $(p<0.05)$. 

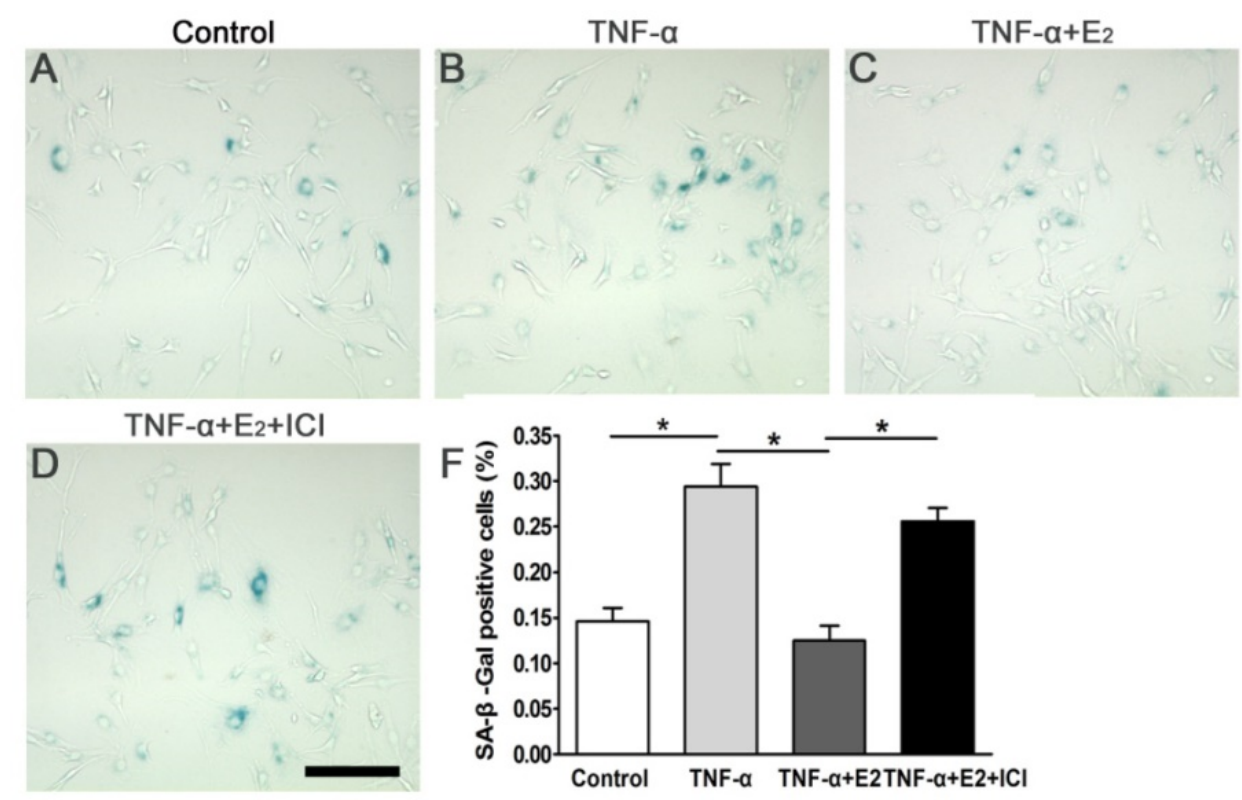

Figure 3. 17beta-estradiol $\left(E_{2}\right)$ reduced SA- $\beta$-Gal activity of the TNF- $\alpha$-treated nucleus pulposus (NP) cells. NP cells were incubated with different test compounds for 24 hours. Magnification: $200 \mathrm{x}$, scale $=100 \mu \mathrm{m}$. Data are expressed as the mean \pm SD $(n=3)$. *: significant difference between two groups $(\mathrm{p}<0.05)$.

\section{$E_{2}$ increased telomerase activity of TNF-a-treated NP cells}

Senescent cells often have decreased telomerase activity. Figure 4 shows that TNF-a significantly decreased the telomerase activity of the NP cells compared to the control group, whereas $E_{2}$ significantly increased the telomerase activity of the TNF-a-treated NP cells. When the ER function was antagonized by ICI 182780, the telomerase activity of the E2-treated NP cells was markedly decreased. These results demonstrated that TNF- $\alpha E_{2}$ can significantly decrease the telomerase activity of TNF-a-treated NP cells through ER function.

\section{$E_{2}$ decreased the percentage of $G 1$ phase TNF- $\alpha$-treated NP cells}

G1 cell cycle arrest is another important characteristic of senescent cells. To fully study the effects of $E_{2}$ on TNF- $a$-induced NP cell senescence, we analyzed cell the cycle in this study. As shown in the Figure 4, TNF-a-treated NP cells were easier to arrest in the G1 phase than that in the control group (Figure 5). $E_{2}$ could attenuate the G1 phase arrest of NP cells treated with TNF-a. However, the ER antagonist ICI 182780 abolished the effects of $E_{2}$ on the NP cell cycle. These findings suggest that TNF- $\alpha$ can inhibit NP cell growth whereas $\mathrm{E}_{2}$ can attenuate TNF-a-induced cell cycle arrest in NP cells.

\section{$E_{2}$ increased the expression of matrix macromolecules in TNF- $\alpha$-treated NP cells}

Attenuated matrix synthesis is regarded as a senescence-associated cellular phenotype. Previous studies have demonstrated that senescent cells have limited anabolic metabolism $[37,38]$. In this study, we also investigated matrix synthesis in NP cells by evaluating the gene expression and protein deposition of matrix macromolecules (aggrecan and collagen II). As shown in Figure 6, though matrix molecule (aggrecan and collagen II) expression and matrix deposition were decreased in the TNF-a-treated NP cells, $\mathrm{E}_{2}$ significantly abolished the inhibitory effects of TNF-a on matrix molecule expression and matrix deposition. Additionally, the inhibition of ER function by ICI 182780 significantly decreased matrix molecule expression and matrix deposition in the $\mathrm{E}_{2}$-treated NP cells. Collectively, these results indicate that $\mathrm{E}_{2}$ can promote matrix synthesis in TNF-a-treated NP cells through ER function.

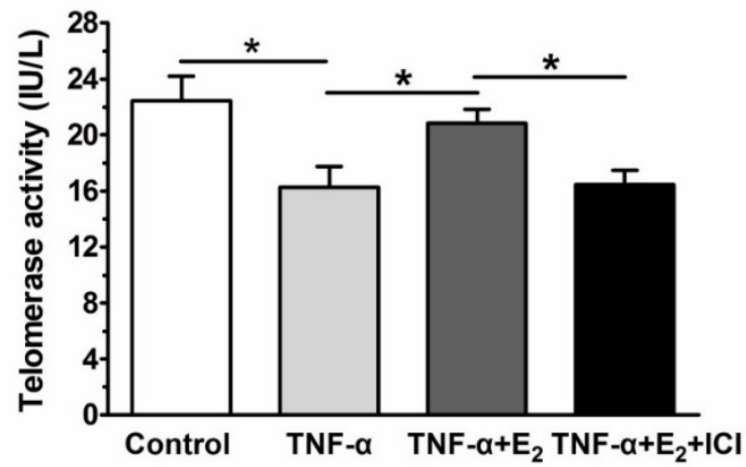

Figure 4. 17beta-estradiol $\left(E_{2}\right)$ increased the telomerase activity of TNF- $\alpha$-treated nucleus pulposus (NP) cells. NP cells were incubated with different test compounds for 24 hours. Data are expressed as the mean $\pm S D(n=3)$. *: significant difference between two groups $(p<0.05)$. 

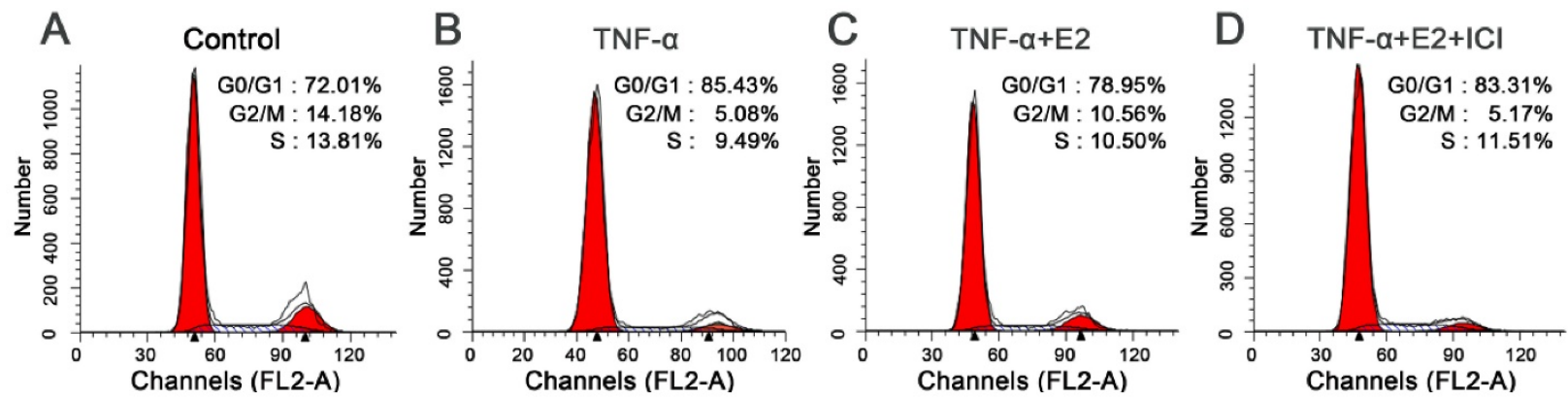

Figure 5. 17beta-estradiol ( $\left.E_{2}\right)$ decreased the percentage of $\mathrm{G} 1$ phase TNF- $\alpha$-treated nucleus pulposus (NP) cells. NP cells were incubated with different test compounds for 24 hours. The percentage of NP cells in the G0/G1, G2/M and S phases in each group was shown in the respective images.

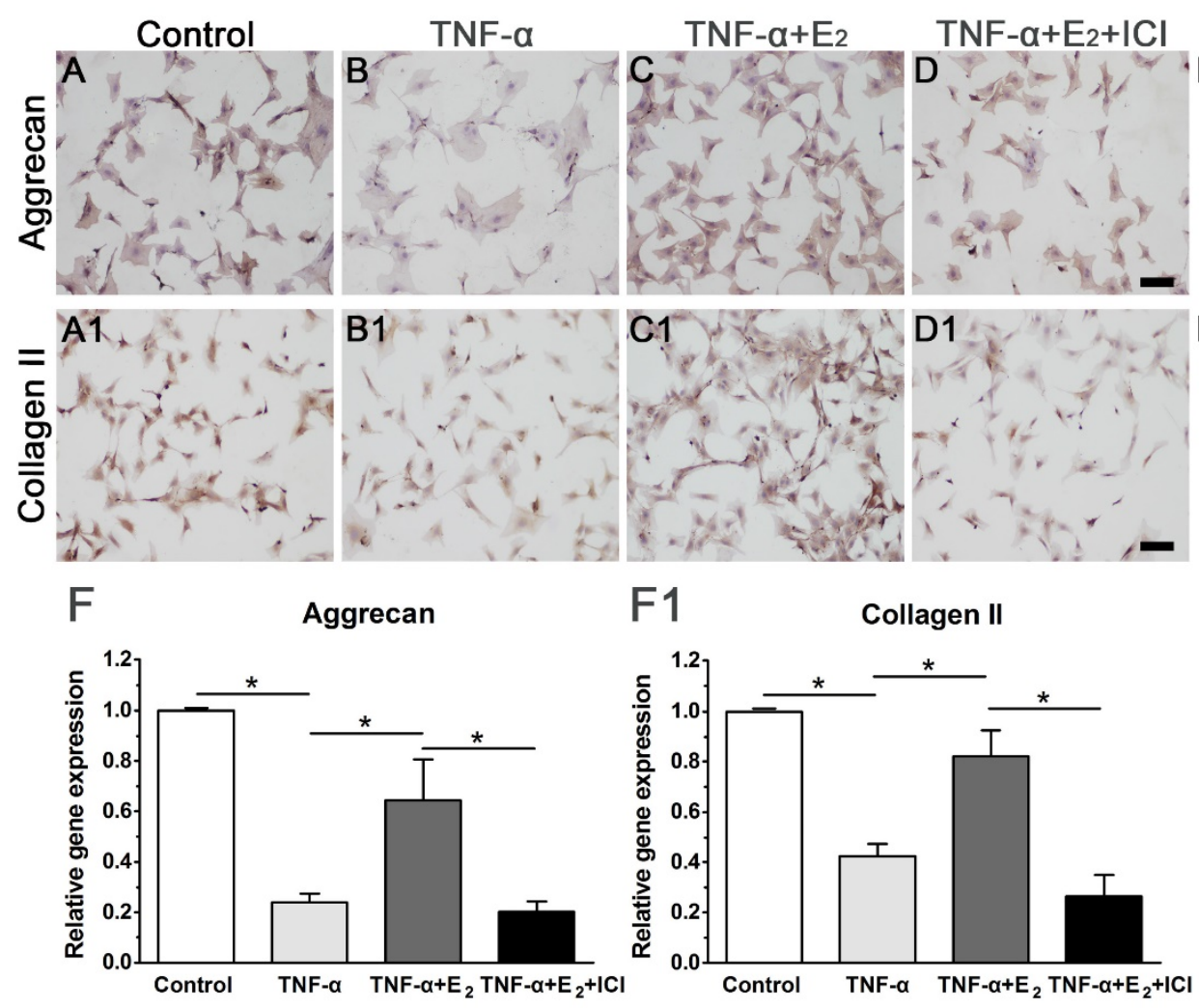

Figure 6. 17beta-estradiol $\left(E_{2}\right)$ up-regulated the expression of matrix macromolecules in TNF-a-treated nucleus pulposus (NP) cells. NP cells were incubated with different test compounds for 24 hours. A-D: immunocytochemistry staining of aggrecan. Al-D1: immunocytochemistry staining of collagen II. E and E1: quantification of staining intensity of aggrecan and collagen II, respectively. F and Fl: real-time PCR analysis of aggrecan mRNA and collagen II mRNA, respectively. NP cells were incubated with different test compounds for 24 hours. Data are expressed as the mean $\pm S D(n=3)$. *: significant difference between two groups $(p<0.05)$.

$E_{2}$ decreased the expression of senescent markers in TNF-a-treated NP cells

Because p53 and p16 are two classic markers of cell senescence, their gene and protein expression were investigated. Consistent with our previous work (unpublished), TNF-a significantly up-regulated the expression of p53 and p16 compared with the control group at both the gene and protein levels in this study. However, $E_{2}$ decreased the expression of both p53 and p16 in NP cells treated with TNF-a. As expected, suppression of ER function also markedly abolished the inhibitory effects of $\mathrm{E}_{2}$ on expression of senescent markers in TNF-a-treated NP cells (Figure 7). Taken together, these results again indicate that the interaction between $\mathrm{E}_{2}$ and $\mathrm{ER}$ can attenuate TNF-a-induced NP cell senescence.

\section{$E_{2}$ decreased ROS generation and NF-KB activity in TNF- $\alpha$-treated NP cells}

Inflammatory cytokines can lead to the generation of ROS, which is regarded as an intracellular messenger of NF-KB activation. Activation of NF-KB has been reported to promote the expression of molecules that regulate various cellular processes, including proliferation, growth and adhesion.[14, 18]. As shown in Figure 8, the inflammatory cytokine TNF- $\alpha$ can significantly increase ROS generation in NP cells, whereas $\mathrm{E}_{2}$ markedly decreased ROS generation in TNF-a-treated 
NP cells. As expected, the effects of $E_{2}$ on ROS generation were reversed by the ER antagonist ICI 182780. Then, we further analyzed the NF-kB activity of NP cells in each group. The result indicated that NF- $\mathrm{KB}$ activity in the TNF-a-treated NP cells was increased compared with that in the control NP cells, whereas NF-kB activity in the TNF-a-treated NP cells was also inhibited by $E_{2}$ incubation. Moreover, the
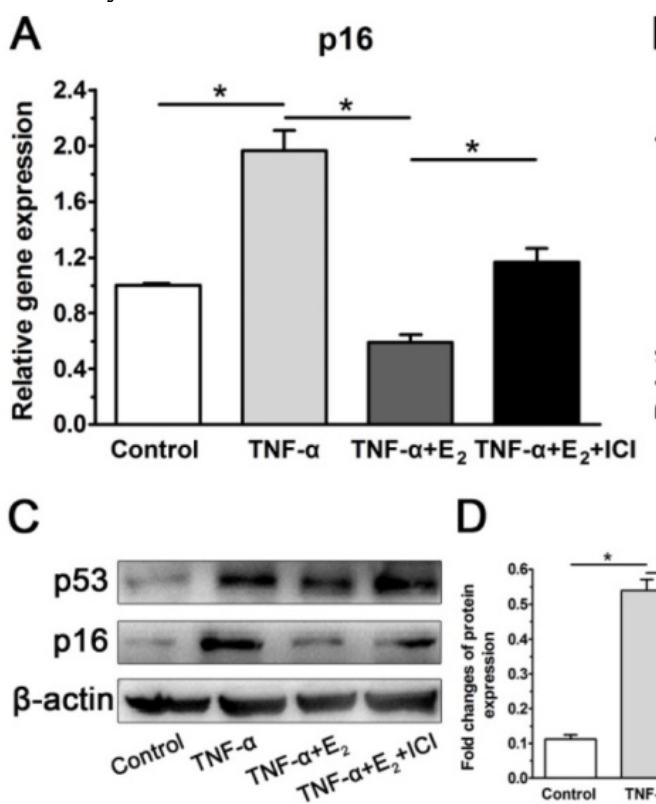

effects of $E_{2}$ on NF-KB activity were also inhibited by the ER antagonist ICI 182780. Combining these findings with the inhibitory effects of $E_{2}$ on the TNF-a-induced senescence-associated phenotype of $\mathrm{NP}$ cells, we speculated that the ROS/NF-kB pathway may be involved in the protective effects of $\mathrm{E} 2$ against TNF-a-induced NP cell senescence.
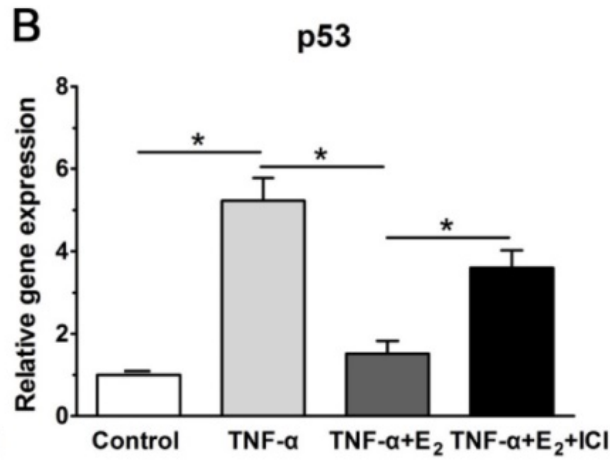

$\mathrm{E}$
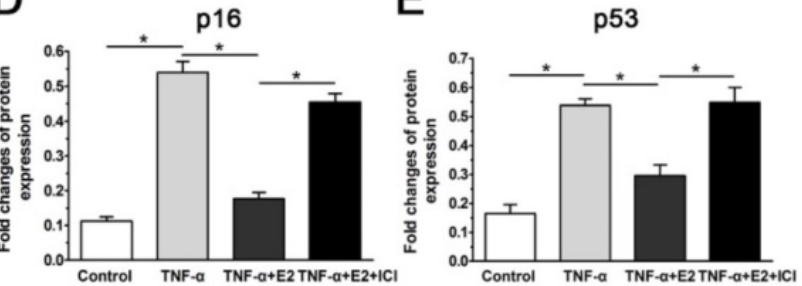

Figure 7. 17beta-estradiol $\left(E_{2}\right)$ down-regulated the expression of senescent markers in TNF-a-treated nucleus pulposus (NP) cells. NP cells were incubated with different test compounds for 24 hours. A and B: real-time PCR analysis of p 16 mRNA and p53 mRNA, respectively. C-E: western blotting analysis of senescence markers ( 16 and $p 53$ ). Data are expressed as the mean $\pm S D(n=3)$. *: significant difference between two groups $(p<0.05)$.

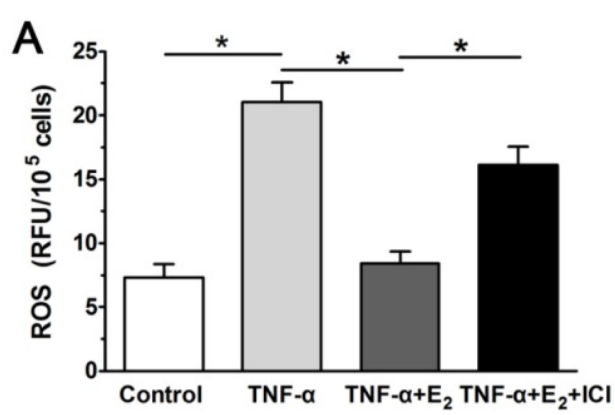

B
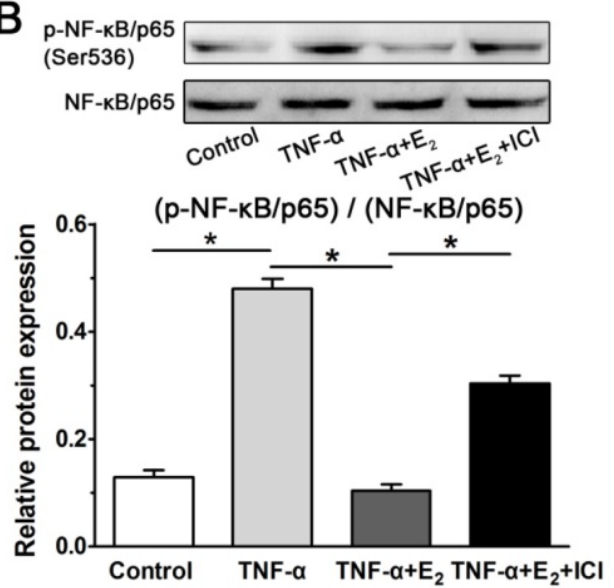

Figure 8. 17beta-estradiol $\left(E_{2}\right)$ decreased ROS generation (A) and NF-KB activity (B) in TNF- $\alpha$-treated nucleus pulposus (NP) cells. Data are expressed as the mean \pm SD $(n=3)$. *: significant difference between two groups $(p<0.05)$.

\section{Part 2: Results of the ex-vivo disc organ culture study}

The disc organ culture system is regarded as a preferable platform for studying NP cell biology because disc NP cells are maintained in their natural matrix environment [39]. To further verify the protective effects of $E_{2}$ on the TNF-a-induced premature senescence of NP cells, we performed an ex-vivo disc organ culture study. As shown in Figure 9, TNF-a promoted premature senescence of NP cells in the disc organ culture, which was indicated by the decreased GAG and HYP contents, down-regulated matrix macromolecule (aggrecan and collagen II) expression, attenuated immunostaining of matrix protein (aggrecan and collagen II) and increased senescence marker (p16 and p53) expression within the NP tissue. Similar with the NP cell culture study, all these effects of TNF- $\alpha$ on the NP cells were restrained by $\mathrm{E}_{2}$ to some extent. However, the ER antagonist ICI 182780 in turn significantly abolished the protective effects of $E_{2}$. Taken together, these 
results of the rat disc organ culture indicate that interactions between $E_{2}$ and $E R$ can attenuate the
TNF-a-induced senescence-associated phenotype of NP cells.
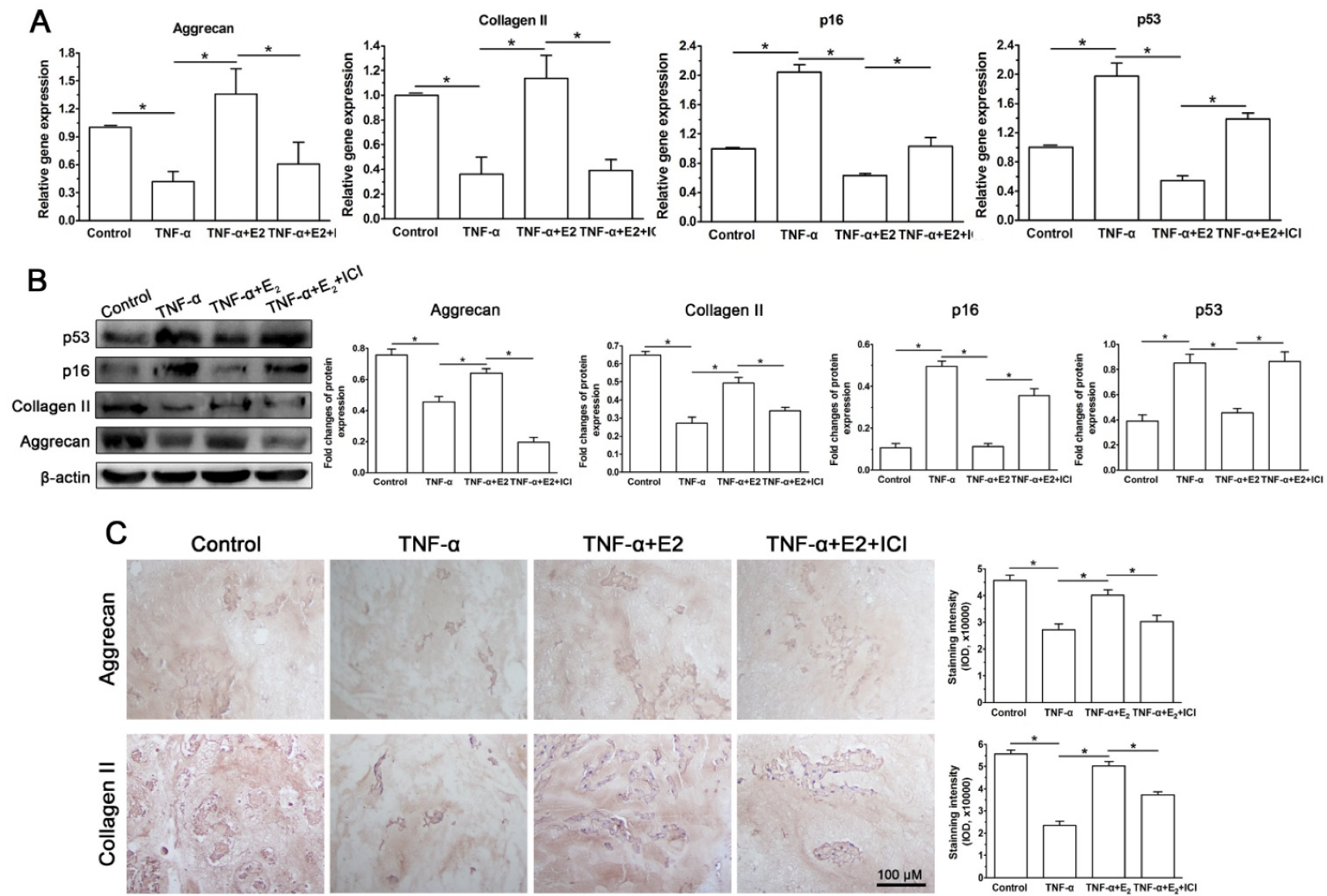

TNF- $\alpha+E 2$

$\mathrm{TNF}-\alpha+\mathrm{E} 2+\mid \mathrm{Cl}$
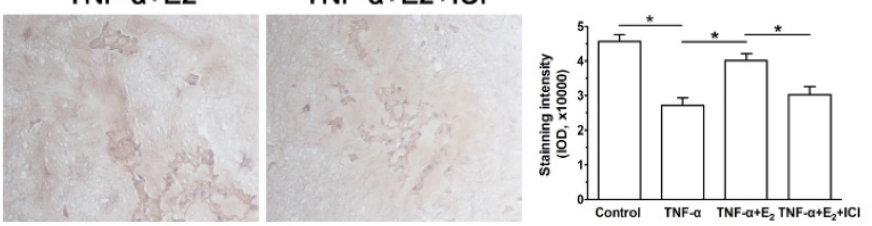

D
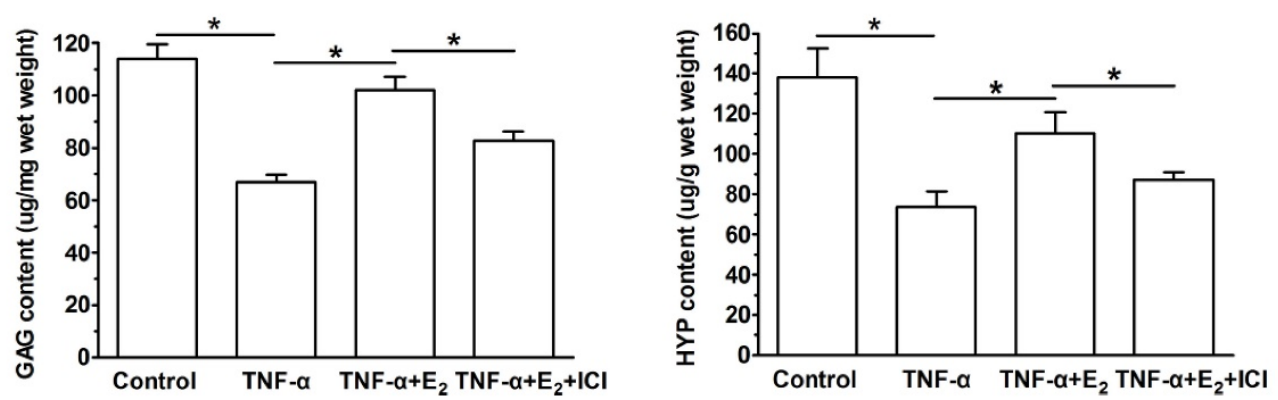

Figure 9. 17beta-estradiol $\left(E_{2}\right)$ down-regulated the expressions levels of senescence markers ( $\mathrm{p} 16$ and $\mathrm{p} 53$ ) and matrix macromolecules (aggrecan and collagen II) and decreased matrix protein (aggrecan and collagen II) deposition and biochemical content (GAG and HYP) within the nucleus pulposus (NP) tissue from the ex-vivo organ-cultured rat discs. Rat discs were organ-cultured for 10 days in different test compounds. A: gene expression of senescence markers (p16 and p53) and matrix macromolecules (aggrecan and collagen II). B: protein expression of senescence markers (p16 and p53) and matrix macromolecules (aggrecan and collagen II). C: immunohistochemical staining of aggrecan and collagen II. D: GAG and HYP content measurement. Data are expressed as the mean $\pm S D(n=3)$. *: significant difference between two groups ( $<<0.05)$.

\section{Discussion}

Cellular senescence accumulation within the disc NP tissue is a classical pathological phenomenon during disc degeneration [40]. In line with other studies on the relationship between inflammatory cytokines and cellular senescence, we previously found that the inflammatory cytokine TNF-a could promote premature senescence of NP cells (unpublished). Several previous clinical studies have indicated the connective tissue of the intervertebral disc is negatively affected by estrogen deficiency, whereas it is positively affected by estrogen supplements [21, 23]. However, the underlying molecule mechanisms are not well studied. To our knowledge, this is the first study to report the effects of estrogen on TNF-a-induced premature senescence of rat NP cells. We speculate that $\mathrm{E}_{2}$ may attenuate TNF-a-induced premature senescence of NP cells through the function of ER. To elucidate this hypothesis, a series of experiments were performed using the NP cell culture system and the ex-vivo disc 
organ culture system in the present study.

In this study, TNF-a could induce premature senescence of rat NP cells based on cell proliferation, cell cycle, telomerase activity, SA- $\beta$-Gal activity and the expression of matrix macromolecules (aggrecan and collagen II) and senescence markers (p53 and p16), which is in line with our preliminary study (unpublished). However, $\mathrm{E}_{2}$ attenuated the senescence-associated phenotype in TNF-a-treated NP cells. Moreover, the ER antagonist ICI 182780 abolished the protective effects of $E_{2}$ against TNF-a-induced premature senescence of NP cells. Inflammatory cytokine TNF- $\mathrm{a}$, as a cellular stress factor, can lead to the generation of ROS, which in turn activates several signaling molecules along cell apoptosis and cell proliferation pathways, such as NF-кB. In this study, we found that the interaction between $\mathrm{E}_{2}$ and $\mathrm{ER}$ can significantly decrease ROS generation and NF-kB activity. Taken together, our results demonstrated that the interaction between $E_{2}$ and ER attenuated TNF-a-induced premature senescence of NP cells, and that the ROS/NF-кB pathway may be an important regulatory mechanism behind this process.

In light of the accumulation of senescent disc cells within degenerated discs [8, 10], a comprehensive description of the senescent disc cells is necessary. Conventionally, senescent cells often display decreased cell proliferation ability, increased SA- $\beta$-Gal activity and marked G1 cell cycle arrest [41, 42]; therefore, we used the CCK-8 assay, SA- $\beta-G a l$ staining and cell cycle analysis to evaluate NP cell senescence in this study. The results showed that $E_{2}$ increased cell proliferation potency, decreased SA- $\beta$-Gal activity and inhibited G1 cell cycle arrest in NP cells treated with TNF-a. Because TNF-a is one type of main inflammatory cytokine within degenerated discs [13, 17, 31, 32, 43], our results indirectly indicate that $\mathrm{E}_{2}$ can attenuate the premature senescence of NP cells surrounded by an inflammatory microenvironment. In line with the presented protective effects of $E_{2}$ on NP cells, previous studies also demonstrated that $E_{2}$ could retard the senescence of other cells including mesenchymal stem cells, chondrocytes, vascular epithelial cells and vascular smooth cells [34, 44, 45]. Additionally, E2 can also inhibit apoptosis of disc cell and increase the proliferation potency of disc cells [25-28]. All these studies indicate that $E_{2}$ partly plays a protective role in disc biology.

Though senescent cells are viable and also metabolically active, their expression profile of catabolic enzymes is substantially altered, which may affect normal extracellular matrix production within the tissue $[37,38]$. In this study, though the expression of matrix macromolecules (aggrecan and collagen II) was down-regulated by the inflammatory cytokine TNF-a, $E_{2}$ could up-regulate the expression these matrix macromolecules in TNF-a-treated NP cells. Similarly, in other research fields $[46,47], \mathrm{E}_{2}$ has also been shown to increase the production of glycosaminoglycan and collagen, which are basic components of intervertebral discs. On the other hand, the decline in natural matrix content is a common outcome both in the degenerated and aged discs $[48,49]$. Because the changes of matrix synthesis within disc tissue can significantly affect the shape and biomechanics of intervertebral discs [50], we deduced that the described effects of $E_{2}$ on the basic matrix of intervertebral discs may partly explain the previous reports [23] that $\mathrm{E}_{2}$ supplementation can increase disc height in postmenopausal women.

Theoretically, two mechanisms are responsible for cellular senescence: the telomere-based p53-p21-pRB pathway and the stress-based p16-pRB pathway [51]. Previously, several studies investigated these two senescent pathways in the disc and demonstrated that up-regulation of p53 or p16 occurred in aged or degenerated disc cells [7, 9, 52, 53]. In this study, the expression of p53 and p16 in TNF-a-treated NP cells was up-regulated compared with control NP cells, which further confirmed our preliminary findings (unpublished). However, $\mathrm{E}_{2}$ simultaneously suppressed the expression of these two senescence markers (p53 and p16) and decreased telomerase activity in TNF-a-treated NP cells. These results indicated that $\mathrm{E}_{2}$ can attenuate the TNF-a-induced premature senescence of NP cells.

Although obvious positive effects of $E_{2}$ on TNF-a-treated NP cells were observed, these effects were significantly reversed by the ER antagonist ICI 182780, indicating that the interaction between $\mathrm{E}_{2}$ and ER plays an important role in suppressing TNF-a-induced NP cell senescence. Previous studies have demonstrated that the inflammatory cytokine TNF-a can cause generation of ROS, which is a common step in NF-kB activation that participates in cell apoptosis and cell proliferation [14, 18, 54]. In this study, we also investigated the intracellular ROS generation and NF-KB activity to reveal the possible mechanism behind the protective effects of $E_{2}$ against TNF-a-induced NP cell senescence. The results showed that TNF-a can significantly increase ROS generation and NF- $\mathrm{kB}$ activity in NP cells. By contrast, this can be partly reversed by the interaction between $\mathrm{E}_{2}$ and ER. Combining this result with the inhibitory effects of E2 on TNF-a-induced NP cell senescence, it can be speculated that the interaction between E2 and ER may attenuate TNF-a-induced NP cell senescence through interfering with the ROS/NF-kB pathway. 
To further verify the protective role of $\mathrm{E}_{2}$ against the premature senescence of TNF-a-treated NP cells, we performed similar experiments using ex-vivo rat disc organ cultures. This experiment may be closer to the physiological situation because the disc NP cells are maintained in their natural matrix environment. Corresponding to the results from the rat NP cell culture system, the intact rat disc incubated with TNF- $\alpha$ showed increased expression levels of senescence markers (p53 and p16), down-regulated matrix protein expression (aggrecan and collagen II), decreased matrix protein deposition and decreased biochemical content within the NP tissue. In line with our study, a previous study [35] also demonstrated that TNF-a treatment of organ-cultured bovine discs caused a non-recoverable catabolic shift that was characterized by aggrecan degradation, increased matrix degrading enzymes and increased SA- $\beta$-Gal immunostaining. Furthermore, we also found that the addition of $E_{2}$ to the culture medium partly counteracted the TNF-a-induced down-regulation of matrix protein expression and up-regulation of senescence markers and that the effects of $E_{2}$ were abolished by the ER antagonist ICI 182780. All these results were in line with those from the NP cell culture, further indicating that the interaction between $E_{2}$ and ER may protect against TNF-a-induced premature senescence of NP cells.

This study also has several limitations. First, classic ER is made up of two forms including ERa and ER $\beta$. In this study, because we primarily focused on the positive effects of $E_{2}$, we did not investigate which $E R$, either ERa or ER $\beta$, participates in this regulatory process. This question can be answered in the future by using certain specific commercial ligands of ERa and ER $\beta$. Second, ER knockdown experiments would help confirm the role of ER from another aspect. However, because the ER inhibitor ICI 182780 is widely used in basic research and has been proven to effectively inhibit ER function [25], we did not further perform knockdown experiments to confirm the role of ER in the present study. If possible, the knockdown experiments will be done when we investigate which ER is involved in this regulatory process in the future research.

Based on these presented findings, we draw the conclusion that the interaction between $E_{2}$ and $E R$ partly attenuates TNF-a-induced premature senescence of rat NP cells through regulating the ROS/NF-kB pathway. This study sheds a light on the counteractive effect of $E_{2}$ on the premature senescence of NP cells and ultimately contributes to understanding the mechanism underlying the positive effects of $E_{2}$ supplementation on intervertebral discs in postmenopausal women.

\section{Acknowledgment}

We would like to thank Doctor Fu-yun Ji for her technical assistance.

\section{Contributions}

Conception and design of this study: Pei Li and Qiang Zhou. Collection, analysis and explanation of the experiment data: Pei Li, Yibo Gan, Lei Luo, Chen Zhao and Qiang Zhou. Drafting and critically revising of the manuscript: Pei Li, Liyuan Wang, Bin Ouyang, Chengmin Zhang and Qiang Zhou. All authors approved the final submission.

\section{Financial support}

This study was supported by the National Natural Science Foundation of China (81272029 and 81027005), and the Science and Technology Achievement Transformation Fund of Third Military Medical University (2011XZH006).

\section{Conflicts of interest}

The authors do not have any conflicts of interest related to this work.

\section{References}

1. Shvartzman L, Weingarten E, Sherry H, Levin S, Persaud A. Cost-effectiveness analysis of extended conservative therapy versus surgical intervention in the management of herniated lumbar intervertebral disc. Spine. 1992; 17: 176-82.

2. Freemont AJ, Watkins A, Le Maitre C, Jeziorska M, Hoyland JA. Current understanding of cellular and molecular events in intervertebral disc degeneration: implications for therapy. The Journal of pathology. 2002; 196: 374-9.

3. Freemont TJ, LeMaitre C, Watkins A, Hoyland JA. Degeneration of intervertebral discs: current understanding of cellular and molecular events, and implications for novel therapies. Expert reviews in molecular medicine. 2001; 2001: 1-10.

4. An HS, Anderson PA, Haughton VM, Iatridis JC, Kang JD, Lotz JC, et al. Introduction: disc degeneration: summary. Spine. 2004; 29: 2677-8.

5. Vo NV, Hartman RA, Patil PR, Risbud MV, Kletsas D, Iatridis JC, et al. Molecular mechanisms of biological aging in intervertebral discs. Journal of orthopaedic research : official publication of the Orthopaedic Research Society. 2016.

6. Boos N, Weissbach S, Rohrbach H, Weiler C, Spratt KF, Nerlich AG. Classification of age-related changes in lumbar intervertebral discs: 2002 Volvo Award in basic science. Spine. 2002; 27: 2631-44.

7. Heathfield SK, Le Maitre CL, Hoyland JA. Caveolin-1 expression and stress-induced premature senescence in human intervertebral disc degeneration. Arthritis research \& therapy. 2008; 10: R87.

8. Gruber HE, Ingram JA, Norton HJ, Hanley EN, Jr. Senescence in cells of the aging and degenerating intervertebral disc: immunolocalization of senescence-associated beta-galactosidase in human and sand rat discs. Spine. 2007; 32: 321-7.

9. Kim KW, Ha KY, Lee JS, Na KH, Kim YY, Woo YK. Senescence of nucleus pulposus chondrocytes in human intervertebral discs. Asian Spine J. 2008; 2: $1-8$.

10. Roberts S, Evans EH, Kletsas D, Jaffray DC, Eisenstein SM. Senescence in human intervertebral discs. European spine journal : official publication of the European Spine Society, the European Spinal Deformity Society, and the European Section of the Cervical Spine Research Society. 2006; 15 Suppl 3: S312-6.

11. Johnson ZI, Schoepflin ZR, Choi H, Shapiro IM, Risbud MV. Disc in flames: Roles of TNF-alpha and IL-1beta in intervertebral disc degeneration. European cells \& materials. 2015; 30: 104-16; discussion 16-7.

12. Phillips KL, Chiverton N, Michael AL, Cole AA, Breakwell LM, Haddock G, et al. The cytokine and chemokine expression profile of nucleus pulposus cells: implications for degeneration and regeneration of the intervertebral disc. Arthritis research \& therapy. 2013; 15: R213.

13. Wuertz $\mathrm{K}$, Haglund L. Inflammatory mediators in intervertebral disk degeneration and discogenic pain. Global spine journal. 2013; 3: 175-84. 
14. Wuertz K, Vo N, Kletsas D, Boos N. Inflammatory and catabolic signalling in intervertebral discs: the roles of NF-kappaB and MAP kinases. European cells \& materials. 2012; 23: 103-19; discussion 19-20.

15. Klawitter M, Quero L, Klasen J, Liebscher T, Nerlich A, Boos N, et al. Triptolide exhibits anti-inflammatory, anti-catabolic as well as anabolic effects and suppresses TLR expression and MAPK activity in IL-1beta treated human intervertebral disc cells. European spine journal : official publication of the European Spine Society, the European Spinal Deformity Society, and the European Section of the Cervical Spine Research Society. 2012; 21 Suppl 6: S850-9.

16. Quero L, Klawitter M, Schmaus A, Rothley M, Sleeman J, Tiaden AN, et al. Hyaluronic acid fragments enhance the inflammatory and catabolic response in human intervertebral disc cells through modulation of toll-like receptor 2 signalling pathways. Arthritis research \& therapy. 2013; 15: R94.

17. Le Maitre CL, Freemont AJ, Hoyland JA. The role of interleukin-1 in the pathogenesis of human intervertebral disc degeneration. Arthritis research \& therapy. 2005; 7: R732-45.

18. Janssens S, Beyaert R. Functional diversity and regulation of different interleukin-1 receptor-associated kinase (IRAK) family members. Molecular cell. 2003; 11: 293-302.

19. Zhang Y, Herbert BS, Rajashekhar G, Ingram DA, Yoder MC, Clauss M, et al. Premature senescence of highly proliferative endothelial progenitor cells is induced by tumor necrosis factor-alpha via the p38 mitogen-activated protein kinase pathway. FASEB J. 2009; 23: 1358-65.

20. Clerigues V, Guillen MI, Gomar F, Alcaraz MJ. Haem oxygenase-1 counteracts the effects of interleukin-1beta on inflammatory and senescence markers in cartilage-subchondral bone explants from osteoarthritic patients. Clin Sci (Lond). 2012; 122: 239-50.

21. Wang YX, Griffith JF. Effect of menopause on lumbar disk degeneration: potential etiology. Radiology. 2010; 257: 318-20.

22. Miller JA, Schmatz C, Schultz AB. Lumbar disc degeneration: correlation with age, sex, and spine level in 600 autopsy specimens. Spine. 1988; 13: 173-8.

23. Baron YM, Brincat MP, Galea R, Calleja N. Intervertebral disc height in treated and untreated overweight post-menopausal women. Human reproduction (Oxford, England). 2005; 20: 3566-70.

24. Wang T, Zhang L, Huang C, Cheng AG, Dang GT. Relationship between osteopenia and lumbar intervertebral disc degeneration in ovariectomized rats. Calcified tissue international. 2004; 75: 205-13.

25. Yang SD, Ma L, Gu TX, Ding WY, Zhang F, Shen Y, et al. 17beta-Estradiol protects against apoptosis induced by levofloxacin in rat nucleus pulposus cells by upregulating integrin alpha2beta1. Apoptosis : an international journal on programmed cell death. 2014; 19: 789-800.

26. Yang SD, Yang DL, Sun YP, Wang BL, Ma L, Feng SQ, et al. 17beta-estradiol protects against apoptosis induced by interleukin-1beta in rat nucleus pulposus cells by down-regulating MMP-3 and MMP-13. Apoptosis : an international journal on programmed cell death. 2015; 20: 348-57.

27. Wang H, Ding W, Yang D, Gu T, Yang S, Bai Z. Different concentrations of 17beta-estradiol modulates apoptosis induced by interleukin-1beta in rat annulus fibrosus cells. Molecular medicine reports. 2014; 10: 2745-51.

28. Gruber HE, Yamaguchi D, Ingram J, Leslie K, Huang W, Miller TA, et al. Expression and localization of estrogen receptor-beta in annulus cells of the human intervertebral disc and the mitogenic effect of 17-beta-estradiol in vitro. BMC musculoskeletal disorders. 2002; 3: 4

29. Yang SD, Ma L, Yang DL, Ding WY. Combined effect of 17 beta-estradiol and resveratrol against apoptosis induced by interleukin-1beta in rat nucleus pulposus cells via PI3K/Akt/caspase-3 pathway. PeerJ. 2016; 4: e1640.

30. Jeong SW, Lee JS, Kim KW. In vitro lifespan and senescence mechanisms of human nucleus pulposus chondrocytes. Spine J. 2014; 14: 499-504.

31. Weiler C, Nerlich AG, Bachmeier BE, Boos N. Expression and distribution of tumor necrosis factor alpha in human lumbar intervertebral discs: a study in surgical specimen and autopsy controls. Spine. 2005; 30: 44-53; discussion 4

32. Le Maitre CL, Hoyland JA, Freemont AJ. Catabolic cytokine expression in degenerate and herniated human intervertebral discs: IL-1beta and TNFalpha expression profile. Arthritis research \& therapy. 2007; 9: R77.

33. Hattori $\mathrm{Y}$, Kojima T, Kato D, Matsubara H, Takigawa M, Ishiguro N. A selective estrogen receptor modulator inhibits tumor necrosis factor-alpha-induced apoptosis through the ERK1/2 signaling pathway in human chondrocytes. Biochemical and biophysical research communications. 2012; 421: 418-24.

34. Breu A, Sprinzing B, Merkl K, Bechmann V, Kujat R, Jenei-Lanzl Z, et al. Estrogen reduces cellular aging in human mesenchymal stem cells and chondrocytes. Journal of orthopaedic research : official publication of the Orthopaedic Research Society. 2011; 29: 1563-71.

35. Purmessur D, Walter BA, Roughley PJ, Laudier DM, Hecht AC, Iatridis J. A role for TNFalpha in intervertebral disc degeneration: a non-recoverable catabolic shift. Biochemical and biophysical research communications. 2013; 433: 151-6.

36. Farndale RW, Sayers CA, Barrett AJ. A direct spectrophotometric microassay for sulfated glycosaminoglycans in cartilage cultures. Connective tissue research. 1982; 9: 247-8.

37. van Deursen JM. The role of senescent cells in ageing. Nature. 2014; 509: $439-46$

38. Cristofalo VJ, Lorenzini A, Allen RG, Torres C, Tresini M. Replicative senescence: a critical review. Mechanisms of ageing and development. 2004; 125: 827-48.
39. Junger S, Gantenbein-Ritter B, Lezuo P, Alini M, Ferguson SJ, Ito K. Effect of limited nutrition on in situ intervertebral disc cells under simulated-physiological loading. Spine. 2009; 34: 1264-71.

40. Wang F, Cai F, Shi R, Wang XH, Wu XT. Aging and age related stresses: a senescence mechanism of intervertebral disc degeneration. Osteoarthritis and cartilage / OARS, Osteoarthritis Research Society. 2016; 24: 398-408.

41. Gruber HE, Ingram JA, Davis DE, Hanley EN, Jr. Increased cell senescence is associated with decreased cell proliferation in vivo in the degenerating human annulus. The spine journal : official journal of the North American Spine Society. 2009; 9: 210-5.

42. Hiyama A, Sakai D, Risbud MV, Tanaka M, Arai F, Abe K, et al. Enhancement of intervertebral disc cell senescence by WNT/beta-catenin signaling-induced matrix metalloproteinase expression. Arthritis and rheumatism. 2010; 62: 3036-47.

43. Gruber HE, Hoelscher GL, Ingram JA, Norton HJ, Hanley EN, Jr. Increased IL-17 expression in degenerated human discs and increased production in cultured annulus cells exposed to IL-1ss and TNF-alpha. Biotech Histochem. 2013; 88: 302-10.

44. Ruan Y, Wu S, Zhang L, Chen G, Lai W. Retarding the senescence of human vascular endothelial cells induced by hydrogen peroxide: effects of 17beta-estradiol (E2) mediated mitochondria protection. Biogerontology. 2014; 15: $367-75$

45. Zhu C, Zhang L, Zheng Y, Xu J, Song J, Rolfe BE, et al. Effects of estrogen on stress-induced premature senescence of vascular smooth muscle cells: a novel mechanism for the "time window theory" of menopausal hormone therapy. Atherosclerosis. 2011; 215: 294-300.

46. Baron YM, Galea R, Brincat M. Carotid artery wall changes in estrogen-treated and -untreated postmenopausal women. Obstetrics and gynecology. 1998; 91: 982-6.

47. Carranco A, Reyes R, Huacuja L, Guzman A, Delgado NM. Human urinary glycosaminoglycans as accurate method for ovulation detection. International journal of fertility. 1992; 37: 209-13.

48. Gruber HE, Hanley EN, Jr. Recent advances in disc cell biology. Spine. 2003; 28: 186-93.

49. Buckwalter JA. Aging and degeneration of the human intervertebral disc. Spine. 1995; 20: 1307-14.

50. Wuertz K, Godburn K, MacLean JJ, Barbir A, Donnelly JS, Roughley PJ, et al. In vivo remodeling of intervertebral discs in response to short- and long-term dynamic compression. Journal of orthopaedic research : official publication of the Orthopaedic Research Society. 2009; 27: 1235-42.

51. Beausejour CM, Krtolica A, Galimi F, Narita M, Lowe SW, Yaswen P, et al. Reversal of human cellular senescence: roles of the p53 and p16 pathways. The EMBO journal. 2003; 22: 4212-22.

52. Le Maitre CL, Freemont AJ, Hoyland JA. Accelerated cellular senescence in degenerate intervertebral discs: a possible role in the pathogenesis of intervertebral disc degeneration. Arthritis research \& therapy. 2007; 9: R45.

53. Kim KW, Chung HN, Ha KY, Lee JS, Kim YY. Senescence mechanisms of nucleus pulposus chondrocytes in human intervertebral discs. The spine journal : official journal of the North American Spine Society. 2009; 9: 658-66.

54. Collins T, Cybulsky MI. NF-kappaB: pivotal mediator or innocent bystander in atherogenesis? The Journal of clinical investigation. 2001; 107: 255-64. 